\title{
Efficacy and safety of indacaterol/glycopyrronium in Japanese patients with COPD: a subgroup analysis from the SHINE study [Corrigendum]
}

\author{
Hashimoto S, Ikeuchi H, Murata S, Kitawaki T, Ikeda K, \\ Banerji D. Int J Chron Obstruct Pulmon Dis. 2016;11: \\ 2543-2551. \\ On page 2547, Figure 5, $x$-axis, the dose mentioned in
}

of "110 $\mu \mathrm{g}$ od" and the dose for GLY should have read "50 $\mu \mathrm{g}$ od" instead of "110 $\mu \mathrm{g}$ od". the label for IND should have read " $150 \mu \mathrm{g}$ od" instead

\section{Publish your work in this journal}

The International Journal of COPD is an international, peer-reviewed journal of therapeutics and pharmacology focusing on concise rapid reporting of clinical studies and reviews in COPD. Special focus is given to the pathophysiological processes underlying the disease, intervention programs, patient focused education, and self management protocols.

\section{Dovepress}

This journal is indexed on PubMed Central, MedLine and CAS. The manuscript management system is completely online and includes a very quick and fair peer-review system, which is all easy to use. Visit http://www.dovepress.com/testimonials.php to read real quotes from published authors.

Submit your manuscript here: http://www.dovepress.com/international-journal-of-chronic-obstructive-pulmonary-disease-journal 